\title{
ENGLISH SPELLING: A PROBLEM TO AN L2 LEARNER
}

\author{
MARIJANA CEROVIĆ ${ }^{1}$ \\ University of Montenegro, Faculty of Philology, \\ Department of English Language and Literature, \\ Nikšić, Montenegro
}

S obzirom da su svi pokušaji reforme engleske ortografije bili neuspješni, potrebno je pokloniti puno pažnje najboljim strategijama u nastavi postojećeg sistema. Ovo je posebno bitno u slučaju učenika stranog jezika čiji prvi jezik ima prilično jednostavan odnos ortografije i fonologije. $U$ ovom radu fokusiramo se na neke aspekte engleske ortografije, koji mogu predstavljati problem ovakvom učeniku.

Ključne riječi: engleska ortografija, čitanje, pisanje, učenici drugog stranog jezika, poteškoće u učenju.

\section{INTRODUCTION}

Many descriptions of English as a native language are bound up with teaching reading to young children and the problem of pronouncing a string of letters and associating them with meaning. According to Carney (1995) literacy teaching is more often concerned with receiving written messages than with sending them. However, the fact is that reading English is less risky than writing in English. To support this Henderson and Chard (1980) report that a reader has 19 options in putting together a string of phonemes, while the writer has 27 options in putting together a string of letters, i.e. correspondences are more in the phoneme to grapheme direction.

When it comes to teaching English as a second language, it is usually said that foreign learners use spelling in order to recover pronunciation. Dickerson (1987) proposes use of orthography as a learning tool, students' exposure to spelling based prediction patterns and learner oriented rules of pronunciation. However, the most usual procedure in classroom settings is teaching no spelling based pronunciation. The only thing the pupils are taught is English alphabet and its pronunciation. They are then

1 Kontakt podaci (Email): cmarijana_2000@yahoo.com 
exposed to English texts, until they implicitly learn certain rules. Teachers are generally much more concerned with teaching grammatical rules and the lexicon.

\section{WHAT COMES FROM CONNECTING A SOUND TO A LETTER?}

Even for native speakers, much of the confusion between sounds and letters comes from learning alphabet as a preliminary for reading. In criticizing native English alphabet books Perera (as reported in Carney 1995) says that 'knowing the alphabet' involves learning the letter's shape, its usual phonetic counterparts and its 'name'. The problem arises with the name of the letter because in some cases the letter indeed says its name, but in some this is not the case. For example, the letter <a> says its name in mate, but not in mat. This shows that problems will arise if the names of letters are taken as a basis for describing the writing system in relation to speech.

This problem is even more present in learning English as a second language, especially in the case of $L 2$ learners whose L1 scribe is phonographic, with one letter corresponding to one sound or a number of letters always correspond to a certain sound, which is not the case in English in which one can always find some exceptions to the rule. Another problem arises from the fact that alphabetic systems, which closely relate to the pronunciation of words, have among other things a rather small vowel system, the ratio being usually five vowels in their L1 to 14 / 24 vowels of English. Thus, a foreign learner with such a background might find it very difficult to learn that the vowel letter $<\mathbf{a}>$ is not always /ei/, that it is pronounced as /ei / in words like baby, but not in words like cat. Another problem is that some vowels are represented as digraphs as in dew, bead, feed etc. and also that they are not only represented by using vowel letters but in combination with $>\boldsymbol{y}<$ and $>\mathbf{w}<$. The same problem may arise with consonants: in some cases digraph $<$ th $>$ is pronounced as $/ \boldsymbol{\theta} /$, in some cases as $/ \mathbf{0} /$.

This shows that a learner of English whose $\mathrm{L} 1$ has a more or less a 'phonemic' scribe, and who is furthermore expected to learn English spelling implicitly, will have to conclude that one letter one phoneme will not work in the case of English. He/she will also have to figure out that a string of letters does correspond to a certain phoneme or group of phonemes in certain cases but not in others.

\section{LITERATURE ON READING/WRITING AS SEPARATE PROCESSES}

Additional causes of difficulty in writing/reading are indicated by the broad psycholinguistic literature. A number of authors (ex. Sampson 1985; Brayant and Bradley 1980) have claimed that reading is a separate process from the process of writing. This claim is supported by Brayant and Bradley's experiment (1980). What they have found is that children cannot frequently spell the words which they read correctly and vice versa. Thus, among the words, which are read but not spelled, are: school, light, train, egg etc. while words which are spelled but not read are: bun, leg, pat. Tis may indicate that the separateness of the two processes further complicates teaching reading/writing both to $\mathrm{L} 1$ and $\mathrm{L} 2$ learners. 


\section{PSYCHOLINGUISTIC EVIDENCE ON HOW THE WORDS ARE READ AND SPELLED}

The issue of whether the reader analyses a string of letters at any stage of the reading process into their corresponding phonemes to recognize the word, has been rejected by psycholinguists based on the following: a) the rate of reading is too rapid for that, and b) real words or pronounceable word-shapes are processed more quickly than non-words. It is more likely that grapheme - phoneme correspondences are processed.

Coltheart and Rastle (1994) put forward a "dual route" model when it comes to reading words. The model proposes three ways of reading words: a) the semantic route - having recognized the word, the meaning could be activated and the pronunciation selected; b) lexical route - having recognized the word, a "lexical" entry could be accessed and c) sub-lexical route - having recognized which letters are present in the word, a set of spelling - sound correspondence rules could be applied to derive a pronunciation, and the word does not have to be recognized to be read.

The lexical and semantic routes correspond to what is sometimes referred to as "sight" reading and the sub-lexical route to "phonological recoding/decoding". The fact that people can assign pronunciation to novel words means that there is some sense in which they are able to use the sub-lexical route. This route is used in pronouncing novel regular words. The irregular ones would have to be pronounced via the lexical/ semantic routes. The existence of the "dual route" distinction has found evidence in the research of different types of dyslexia.

When it comes to writing, according to Eysenck and Keane (2010) there are two main routes between hearing a word and spelling it: the lexical route and the non-lexical route. The lexical route contains the information needed to relate phonological (sound), semantic (meaning), and orthographic (spelling) representations of words to each other. This route is used when spelling familiar words. The non-lexical route does not involve gaining access to detailed information about the sound, meaning, and spelling of heard words. Instead, this route uses stored rules to convert sounds or phonemes into groups of letters or graphemes. It is used for spelling unfamiliar words or non-words.

These findings suggest that reading and writing are complex processes each consisting of at least two different psychological routes, therefore, when introduced to children, they should be approached with greatest care.

\section{SOME DIFFICULTIES IN READING ENGLISH AS A SECOND LANGUAGE}

The reading of English would pose different problems to learners of English at different stages of learning.

- At the beginning, a learner whose L1 has a greatly phonemic scribe will have problems figuring out that, differently from his/her L1, a letter or a string of letters in English do not always represent the same phoneme(s).

- After figuring this out, all the regularities in English would not be difficult to read. Thus, <sh> which is in a regular correspondence with /s/ would not be difficult to read as such in: mesh, bush, shrub, ship etc. 
- $\quad$ Even the less regular cases whose patterns recur more frequently would after some exposure be read correctly, such as $<\mathrm{ti}>$ which is read as $/ \mathrm{g} /$ in station, institution, information etc.

- $\quad$ Any less frequent patterns which diverge from the rule more dramatically would be more difficult to read. Thus, <ch> in chandelier is more likely to be read as $/ \mathbf{c} /$ than as $/ \mathrm{s} /$ by the $L 2$ learner of English.

- Decoding a set of vowel letters would prove much worse having in mind that: a) the learners are shifting from a small vowel system to a larger one; b) the fact that the same string of vowel letters may be read in different ways. Consider: <ou > in couch, touch, cough etc.

- According to the above cited psycholinguistic literature: irregular forms have to be learnt by heart and are read via the lexical route. Regular word forms with an irregular "enemy" word is more difficult to read:

$<$ ea $>$ in leaf $v s$. deaf $<00>$ in food vs. foot etc.

- Regular words with no enemy words would be much easier to read: Ex. $<0>$ in hope, joke etc.

- Reading suffixes would not pose a lot of problems, for example suffix -ed, which is spelt as /id/, /d/ and /t/ is not problematic, maybe because the pronunciation of these comes naturally, ex. spelled is much easier pronounced as /spelt/ than /speld/. The problem may arise while reading suffix -ing in which $<$ ng $>$ is not pronounced as $/ \mathbf{n} /$ but as $/ \mathbf{n g} /$.

Even the advanced learners might make mistakes in reading in case of:

- Auxiliary letters: L2 learners of English may well pronounce <wr> of write as /wr/ not as /r/.

- Inert letters: the fact that $<\mathbf{g}>$ in sign is not pronounced, while it is pronounced in signature may also be problematic.

- Empty letters: it is more often than not that non-native speakers pronounce $<\mathbf{b}>$ in debt, doubt etc.

- Homophones: an L2 learner would have to figure out that words like write, right, rite are pronounced in the same manner.

- Morphophonemic tendency of English spelling would not be problematic as there is a recurring pattern to it: divine-divinity; serene-serenity etc.

- Proper names would be problematic, having in mind that they are problematic to a native speaker as well. Given to read the name Sean, an L2 learner would hardly read it as /fwn/.

\section{DIFFICULTIES WHEN WRITING ENGLISH}

There is far more irregularity in the mapping between the sound and the spelling than between the spelling and the sound and this makes writing very difficult for an L2 learner with a largely phonemic spelling system. For instance, the letter sequence <ea> is most frequently pronounced /i:/ in eat, peach etc. however, in spelling the sound /i:/ 
gets far more variants: it is possible to spell it $\mathbf{e a}, \boldsymbol{e e}$, ie or $\boldsymbol{e}$. Moreover, the case of /i:/, is not the most extreme example.

In some cases learners will have more difficulty while writing than while reading. This is, for instance, the case with double letters which are not always predictable in writing. Another problem may be homophones, which must be handled logographically. It is not very likely that a writer, on hearing the word /nait/ would write it as knight just by sounding out the word and converting the phonemes into graphemes.

Difficulties may occur from the fact that very short spoken words may have very long written representations. It is not very likely that on hearing the word / $\theta_{\Lambda} \mathrm{r} / \mathrm{\partial}$ young L1 learner would write it as thorough. The difficulty will be even greater in the case of $\mathrm{L} 2$ learners English $\mathrm{L} 2$ learners.

The above indicates that both $L 1$ and $L 2$ speakers of English (particularly those with a phonemic L1 scribe) may encounter various problems when acquiring English spelling. It looks like its teaching needs much systematization.

\section{CONCLUSION}

This paper draws attention to some of the difficulties that can be caused by the English orthographic system both in L1 and L2 learning. As English orthography is a largely morphophonemic system in which there is no one to one correspondence between individual letters and sounds, even L1 learners may encounter problems when learning how to read or write. The L2 learners whose L1 has a fairly straightforward mapping between orthography and phonology will face even more problems when learning how to read and write in English. Things are not made easier by the fact that no spelling based teaching of English is introduced to the learners of English as an $L 2$.

As psycholinguistic literature suggests that reading and writing are complex processes each consisting of at least two different psychological routes, it is obvious that the separateness of the two processes further complicates teaching reading/ writing both to $\mathrm{L} 1$ and $\mathrm{L} 2$ learners. Therefore, it seems that when introducing these two skills, particularly to very young L2 learners, they should be approached individually and with great care. This particularly calls for introducing innovative teaching methods at various stages in learning how to write and read English.

\section{LITERATURA}

Bryant, P.E. i L. Bradley. 1980. Why children sometimes write words which they cannot read. In U. Frith (ur.) Cognitive processes in spelling. London: Academic Press.

Carney, E. 1995. A survey of English spelling. London: Routledge.

Coltheart, M. and K. Rastle. 1994. Serial processing in reading aloud: Evidence for dual-route models of reading Experimental Psychology: Human Perception and Performance, 20, 1197-1211.

Dickerson, W.B. 1987. Orthography as a pronunciation resource. World Englishes. Tom $6,11-20$. 
Eysenck, M. W. and M.T. Keane. 2010. Cognitive Psychology. A student's handbook. 6th edition. Hove: Psychology Press.

Henderson I. and J. Chard. 1980. The reader's implicit knowledge of orthographic structure. In U. Frith (ur.) Cognitive processes in spelling. New York: Academic Press: $85-116$.

Sampson, G. 1985. Writing Systems. London: Hutchinson.

\section{SUMMARY}

\section{ENGLISH SPELLING: A PROBLEM TO AN L2 LEARNER}

Having in mind that all attempts to reform English spelling have failed through, a lot of attention should be given to the best strategies in teaching the current system. This is particularly important in the case of $L 2$ learners whose $L 1$ has a fairly straightforward mapping between orthography and phonology. In this paper we focus on some aspects of English spelling which might pose problems to such a learner.

KEYWORDS: English spelling, reading, writing, L2 learners, difficulties in learning.

Original scientific paper received 17.02.2016; revised 11.07.2016; accepted 15.07.2016) 